УДК 783.3/784.5+269
DOІ https://doi.org/10.31723/2524-0447-2021-32-1-27

\author{
Юйцзяо Ма \\ ORCID: 0000-0003-4794-5792 \\ аспірантка
}

Національної музичної академії України імені П. І. Чайковського

inem.courses@ukr.net

\title{
РОЛЬ ВОКАЛЬНО-ОПЕРНОГО МИСТЕЦТВА XVIII СТОЛІТТЯ У ФОРМУВАННІ КИТАЙСЬКОЇ АКАДЕМІЧНОЇ ШКОЛИ СПІВУ
}

Мета статmi. Стаття присвячена генезису академічного вокального мистецтва в Китаї, типологічним зв'язкам із європейською вокальною традицією, інтеграції європейського та китайського культурних просторів та місцю оперно-вокальної спадщини європейських композиторів XVIII cm. у формуванні національної академічної школи співу. Методологія роботи. Використано методи історичного та культурологічного аналізу, що дозволяе визначити причинно-наслідкові зв'язки у формуванні академічної національної вокальної культури. $\mathbf{H a -}$ укова новизна полягає у тому, що вперше систематизовано та структуровано процес становлення китайського академічного вокального мистецтва, визначено роль християнських місіонерів, виявлено, які вокальні твори формували вокальну академічну школу в країні. Висновки. Роль оперно-вокальної музики ХVIII ст. у формуванні китайської академічної школи співу має історичні, географічні та ментальні особливості. Непорушність багатовікової традиції професійного музичного (театрально-музичного) мистецтва було розхитано віяннями нового часу. Але иьому передував иілий процес проникнення європейської культури та інтеграції з китайськими традиціями, чому сприяло поширення християнських місій, які водночас були освітніми та культурно-мистецькими осередками. Американські місіонери Блісс Мітчел та Мілред Віант у викладанні спиралися на китайську музику (яку збирали та адаптували до богослужінь) та ораторіальні твори композиторів XVIII cm. Вокальна музика XVIII cm. на етапі формування академічного співу європейського зразка теж була частиною християнських місій, тому виконання «Месї» Г.Ф. Генделя, «Створення світу» Й. Гайдна, Пасхальної ораторії «Kommt eilet und laufet» та кантати «Lobet Gott in seinen Reichen» Й.С. Баха були пов'язані з урочистими заходами до християнських свят. Перші професійні вокалісти, які здобули визнання в Европі (Лан Юйсю, Хуан Юкуй, Чжоу Сяоянь), у свій час отримали освіту в місіонерських осередках, де вивчали західну культуру та мови.

(C) Ма Юйцзяо, 2021 
Ключові слова: вокальна академічна школа, християнські місії в Китаї, вокальна музика XVIII cm., опера, вокальна освіта, музичний meamp.

Ma Yujiao, Postgraduate Student of the Ukrainian National Tchaikovsky Academy of Music

The role of vocal and opera art of the XVIII century in the formation of the Chinese academic school of singing

The aim of the article. The article is devoted to the genesis of academic vocal art in China, typological connections with the European vocal tradition, the integration of European and Chinese cultural and the place of opera and vocal music of European composers of the XVIII century for the formation of the national academic school of singing. The methodology of the work. The methods of historical and culturological analysis are used to determine the causal links in the formation of academic national vocal culture. The scientific novelty is that for the first time the process of formation of the Chinese academic vocal art was systematized and structured, the role of Christian missionaries was determined, which vocal works formed the vocal academic school in the country. Conclusions. The role of opera and vocal music of the XVIII century. in the formation of the Chinese academic school of singing has historical, geographical and mental features. The existence of a long tradition of professional musical (theatrical and musical) art has been shifted by modern trends. But this was preceded by a whole process of penetration of European culture and integration with Chinese traditions, which was facilitated by the spread of Christian missions, which were at the same time educational and cultural and artistic centers. American missionaries Bliss Mitchell and Milred Wiant in their pedagogical practice relied on Chinese music (which was collected and adapted for worship) and oratorio works of composers of the XVIII century. Vocal music of the $X V I I I$ century. at the stage of formation of academic singing of the European model was also part of Christian missions, therefore, the performance of "Messiah" by G. F Handel, "Die Schupfung” by J. Haydn, Easter oratorio "Kommt eilet und laufet" and cantata "Lobet Gott in seinen Reichen" by J. S Bach was associated with solemn events on Christian holidays. The first professional vocalists to gain recognition in Europe (Lang Yuxiu, Huang Youkui, Zhou Xiaoyan) were educated in missionary centers where they studied Western culture and languages.

Key words: Vocal academic school, Christian missions in China, vocal music of the XVIII century, opera, vocal education, musical theater.

Актуальність теми дослідження. Професійне вокальне мистецтво в Китаї у своєму формуванні та розвитку має особливості національного та історичного характеру. Це молода галузь порівняно з європейською та американською школами. Академічний спів розвивався в країні за умови, коли відбувалось розгалуження пісенних напрямів, серед яких 
виокремлювались академічний вокал, заснований на традиціях італійського бельканто та німецької фонетичної школи співу, народний спів, який активізувався з появою фольклорних досліджень, джазовий (блюзовий) вокал, який за декілька років пройшов стрімку еволюцію разом з удосконаленням звукозаписувального обладнання. На етапі становлення китайської академічної вокальної школи сучасні процеси в мистецтві мали найбільший вплив: твори, які з'являлись у той час були популярними серед виконавців (переважно оперна та вокальна музика XIX ст.), ставали основою для формування китайської академічної вокальної традиції; тенденції, які спостерігалися тоді у світі мистецтва, формували генеральний шлях, яким слідували засновники вокальної школи в країні.

Мета статті. Стаття присвячена генезису академічного вокального мистецтва в Китаї, типологічним зв'язкам із європейською вокальною традицією, інтеграції європейського та китайського культурних просторів та місцю оперно-вокальної спадщини європейських композиторів XVIII ст. на формування національної академічної школи співу. Методологія роботи. Використано методи історичного та культурологічного аналізу, що дозволяє визначити причинно-наслідкові зв'язки у формуванні академічної національної вокальної культури. Наукова новизна полягає у тому, що вперше систематизовано та структуровано процес становлення китайського академічного вокального мистецтва, визначено роль християнських місіонерів, виявлено, які вокальні твори формували вокальну академічну школу в країні.

Викладення основного матеріалу. На тлі суспільних змін з'являлись нові форми в різних видах мистецтва, зокрема в музичному. Музика (зокрема вокальна) була тісно зв'язана 3 національним театром. Разом з іншими мистецтвами вона становила синкрезис традиційної Пекінської опери. На початку XX століття багатьма діячами (переважно тими, хто поділяв радикальні погляди на зміну суспільного ладу) вона сприймалася як «рудимент», якого треба позбутися та сформувати новий тип національного театру: «В аспекті літератури та мистецтва Рух 4 травня дав початок революції в усіх сферах, зокрема і театральній - від змісту до форми... Ситуація в театрі склалася досить непроста. Китайська драма західного зразка хуацзюй (白 话, «розмовний спектакль» західного зразка) виникла ще до початку Руху 4 травня та проникла у 
Китай із Заходу. Ще до Сіньхайської революції (1911-1912) в театральних колах почався процес реформування традиційного театру, в результаті якого поєднання «старого» та «нового» театрів сприяло появі модернізованої драми (з початку XX століття до Руху 4 травня вона називалася новою драмою на «іноземний лад»)» [2, с. 32-33].

Проте вокальні традиції Пекінської опери, які мали багатовікову історію, зберігалися та впливали на сучасні тенденції вокального мистецтва. Паралельно з цими тенденціями Пекінська опера стояла на міцних позиціях та продовжувала розвиватися. Як основний вид національного театру в Пекінській опері протягом іï історичного розвитку сформувалися закономірності побудови драматичного дійства, в якому музика не тільки відігравала велику роль, а й була учасником театрального процесу. Пісенні жанри мали чітке місце, використання тих чи інших інтонаційно- мелодичних елементів було прив'язано до характеру та смислу тексту (на кшталт риторичних фігур у бароковій музиці). Особливістю була синхронізація співу з детермінованою системою жестикуляції (те ж стосувалося й танцювальних елементів). Ван Дон Мэй зазначає: «До середини XVII ст. в Китаї сформувались чотири види музичного театру, які складали Пекінську оперу. Кожен із них вирізняється не тільки своєю мелодикою, а й оркестровим супроводом та основним музичним інструментом. Опера Куньцюй, яка виникла в кінці династії Юань початку Мін (1271-1368), досягла своєї популярності в кінці династії Мін - початку Цин, сьогодні зберігається в провінціях Цзянсу та Чжецзян» [1, с. 23]. Розгалужена за стильовими ознаками Пекінська опера мала величезний вплив на сучасне мистецтво, зокрема на формування музично-театрального середовища в різних містах Китаю. Можна провести паралелі еволюції традиційного китайського театру з розвитком оперного мистецтва в Європі з позиції закріплення окремих елементів різних рівнів (інтонаційних, інструментальних, жанрових, драматургічних) у музично-театральній композиції.

Першими європейцями в Китаї, які масово приїздили до країни, були християнські місіонери. Місії різних церков поступово закріплювалися в провінціях та великих містах, формуючи осередки з комплексом різних функцій (релігійної, освітньої, культурної). «Поява християнських місіонерів в Китаї, які привозили європейські інструменти та ознайомили 
місцевих жителів з основами європейської теорії музики; заснування церковних шкіл - перших навчальних закладів європейського зразка; зародження світської музичної освіти. Саме релігійні контакти залишались основним способом проникнення європейської традиції в музичний побут Китаю до середини XIX століття» [5, с. 9]. Значна географічна відстань Китаю від країн Заходу ще довго сприяла збереженню місіонерської константи у взаємозв'язку між цими цивілізаціями, тому концертно-гастрольна діяльність європейських музикантів обмежувалась тими, хто був пов'язаний із місіями, проте відомо, що їх приїзд до Піднебесної активізувався ще у XVIII ст. Miciї європейських та американських церков теж мали різний характер, направлення та мету.

Д. Мартинов наводить слова географа, геолога та мандрівника Фердинанда фон Ріхтгофена, автора терміна «Великий шовковий шлях»: «Німецька протестантська місія значно відрізняється від англо-американських. Вона суворо стежить за освітою своїх послів та відряджає тільки священнослужбовців. Діяльність місіонерів розглядається виключно у релігійному дусі; вона повинна базуватися на співчутті до людства, що не пізнало Христа. Досконалою протилежністю виглядає практицизм американців, а англійські місіонери перебувають десь посередині. Місії цих націй прагнуть поєднувати вивчення християнської релігії з вивченням західної культури» [3, с. 42].

Проте мета місій була значно ширша за окреслену Ріхтгофеном. Вони здійснювали інтеграційну політику входження Китаю в простір європейської культури та створення соціокультурних умов для європейців у країні. Освіта посідала основне місце в цьому процесі, навчальні заклади намагалися охопити якомога більше людей: «Особливе місце серед подібних навчальних закладів займає школа Сюй Хуе - одна 3 перших, яку було створено європейцями в Китаї. Її було засновано у 1849 році французьким священиком Клодом Готтеланом, який утілював у життя ідеї канцлера Сюй Гуанци, ім'я якого носила школа. В школі вивчали китайську мову, літературу, фізику, живопис, музику, іноземні мови (французьку, англійську, латинь). У 1862 році в школі був створений оркестр, який виступав на релігійних святах та мав успіх у публіки. Якісна музична освіта була тією особливістю, яка відрізняла школу Сюй Хуе від інших» [4, с. 55]. У школі працювали китайські та французькі педагоги, освіта була спря- 
мована на європейський тип та розподілена на середню та вищу ланки. Таким чином, учні могли обирати рівень своєї освіти та предмети для вивчення, адже до школи приходили люди різного віку.

Значний внесок у музичну освіту, зокрема вокальну, внесло американське подружжя Віант. Блісс Мітчел Віант здобув диригентську освіту, був висвячений у сан Конференцією старійшин методистської єпископальної церкви. Блісс разом із дружиною Мілред прибули в Пекін у вересні 1923 року. Перший рік вони присвятили вивченню мови, згодом він був запрошений викладати в Янцзинський університет на кафедру теології. Разом із ним викладали три китайці, які отримали освіту в Америці, два англійці, ірландець, швейцарець та троє американців. Б.М. Віант заснував музичний факультет у Янцзинському університеті, а його дружина Мілред викладала вокал та давала власні сольні концерти. Віант шукав класичні та народні китайські мелодії, щоб поєднати їх із китайськими текстами задля створення оригінальних гімнів у богослужіннях китайських християн. У жовтні 1932 року десять студентів Янцзинського університету займалися музикою, що було вдвічі більше порівняно з минулим роком. Вісімдесят студентів брали приватні уроки гри на фортепіано та з вокалу. Так, у М. Віант з'явились перші десять студентів. Основною метою подружжя Віант бачило розповсюдження кращої духовної хорової музики західних композиторів. Вони влаштовували постійні концертні виконання кантатно-ораторіальних творів та залучали якомога більше людей. Так, 18 травня 1928 року в методистській церкві Есбері в Пекіні було вперше виконано «Месію» Г.Ф. Генделя силами студентського хору та оркестру. Учасники події настільки були захоплені твором великого німця та творчим процесом, що багато з них згадували про це виконання як про власну належність до проголошення християнського Євангелія у своїй громаді. Твір виконували кожен рік. Із кожним разом музиканти відчували власну роль у здійсненні таїнства. Найбільша кількість учасників у виконанні ораторії Г.Ф. Генделя була у 1938 році (200 осіб), а у 1936 році у виконанні ораторії брала участь видатна китайська співачка Лан Юйсю. Такі богослужіння тривали до 1951 року. Серед творів студентський хор та оркестр також виконували ораторію «Створення світу» Й. Гайдна (в якій однією із солісток була майбутня зірка китайської опери Хуан Юкуй), Пас- 
хальну ораторію «Kommt eilet und laufet» та кантату «Lobet Gott in seinen Reichen» Й.С. Баха, «Гімн хвали» Ф. Мендельсона, «Реквієм» Й. Брамса. Подружжя Віант більшу частину свого життя присвятили місії в Китаї та розвитку музичного виконавства. Після останнього відвідування Батьківщини в липні 1947 року Віант повернулися в Пекін саме в той момент, коли головою музичного факультету Янцзинського університету стала учениця Б.М. Віанта Сюй Юнь Сан, а вже через рік він став виконувати обов'язки президента навчального закладу. Проте в січні 1949 року китайські комуністи зайняли Пекін, змінилися умови перебування західних місіонерів, тому у квітні 1951 року Віанти покинули Китай назавжди.

Перші китайські оперні співаки отримували освіту саме у школах різних християнських місій. Так, одна з перших виконавиць, легенда китайського оперного мистецтва Чжоу Сяоянь (колоратурне сопрано) отримала середню освіту в шанхайській римо-католицькій школі. Знання європейських мов, які викладалися у цій школі, дозволили співачці в майбутньому безперешкодно інтегруватися в європейське мистецьке середовище. Знаючи європейський оперний репертуар, вона швидко вивчала партії та виконувала їх мовою оригіналу. Значний обсяг іiі репертуару складали партії оперних творів композиторів XIX ст., а також камерної музики композиторів постромантичного періоду (К. Дебюссі, Г. Форе). Незважаючи на те, що в репертуарі видатної виконавиці не було вокальної музики XVIII ст., вона вчила своїх учнів на зразках барокової опери та опери епохи класицизму (Г.Ф Генделя, В.А. Моцарта). Її учениця Фан Інь висловилась, що викладач давала репертуар із творів Г.Ф. Генделя, завдяки чому з'явилась можливість виявляти винахідливість, імпровізувати та самостійно додавати характерність музиці.

Висновки. Оперні твори композиторів XVIII ст. в репертуарі китайських вокалістів та на сценах китайських театрів з'явились не одразу, хоча перші опери китайських композиторів західного зразка спирались на традиції оперної класики саме цієї доби. Проникнення європейської культури в Китай довго було пов'язано з різними християнськими місіями, які були осередками духовного життя та освіти. В межах цих місій відбувалися мистецькі події, тому музичні твори Г.Ф. Генделя, Й.С. Баха, Й. Гайдна звучали на святкуваннях Різдва та Великодніх свят. У Янцзинськиому університеті в Пекіні (першому навчальному 
закладі, де викладали музичні дисципліни, зокрема вокал) американські місіонери Блісс Мітчел та Мілред Віант у викладанні спиралися на китайську музику (яку збирали та адаптували до богослужінь) та ораторіальні твори композиторів XVIII ст. У концертних виставах брали участь перші випускники вокального факультету Шанхайської консерваторії - Лан Юйсю та Хуан Юкуй. Концертно-театральна й викладацька діяльність видатної китайської виконавиці Чжоу Сяоянь була спрямована на європейську оперну та камерно-вокальну класику, своїм учням вона прищеплювала любов до барокової опери та опери епохи класицизму, саме завдяки ним у репертуарі китайських вокалістів з'явилися твори Г.Ф. Генделя, В.А. Моцарта та інших композиторів XVIII століття.

\section{СПИСОК ЛІТЕРАТУРИ}

1. Ван Дон Мэй Великий Шелковый путь в истории китайской музыкальной культуры : автореф. дисс. ... канд. искусствоведения. Санкт-Петербург, 2004. 32 с.

2. Жень Шуай Китайская «образцовая революционная опера»: жанрово-стилевые особенности : дисс. ... канд. искусствоведения. Санкт-Петербург, 2019. 240 с.

3. Мартынов Д.Е. Иностранные миссионеры в Китае XIX начала XX в.: специфика деятельности (на примере провинции Шаньдун). Вестник ТГГПУ. 2008. № 3 (14). С. 40-45.

4. Чень Ин Диалог музыкальных культур Европы и Китая в свете религиозных контактов. Актуальные проблемы высшего музыкального образования. Научно-аналитический, научно-образовательный журнал. Нижний Новгород : Нижегородская государственная консерватория им. М. И. Глинки, 2013. № 2 (28). С. 54-56.

5. Чень Ин Китайская опера XX - начала XXI века: к проблеме освоения европейского опыта : автореф. дисс. ... канд. искусствоведения. Ростов-на-Дону, 2015. 26 с.

6. Wiant A. A. A New Songs For China. Victoria : Trafford Publishing, 2003. $383 \mathrm{p}$.

7. Tieyi Zhang The first generation of Chinese art song : Dis... of Doctor of Musical Arts. Lowa, 2019. 66 p.

\section{REFERENCES}

1. Mei, Wang Dong (2004) The Great Silk Road in the history of Chinese musical culture : abstract of dis... of Ph.D. St. Petersburg, [in Russian].

2. Shuai, Zhen (2019) Chinese «exemplary revolutionary opera»: genre and style features : Dis... of Ph.D. St. Petersburg, [in Russian].

3. Martynov, D. E (2008). Foreign missionaries in China in the 19th early 20th centuries: the specifics of their activities (on the example 
of Shandong province). Bulletin TSHPU. 2008. Vol. 3 (14). P. 40-45. [in Russian].

4. Ying, Chen (2013) Dialogue between the musical cultures of Europe and China in the aspect of religious contacts. Actual problems of higher music education. Scientific analytical, scientific and educational journal. Nizhny Novgorod: Glinka Nizhny Novgorod State Conservatoire, 2013. Vol. 2 (28). P. 54-56. [in Russian].

5. Ying, Chen (2015) Chinese opera of the XX - early XXI century: on the problem of mastering the European experience : abstract of dis ... of Ph.D. Rostov-on-Don. [in Russian].

6. Wiant, A. A. (2003) A New Songs For China. Victoria : Trafford Publishing, [in English].

7. Zhang, Tieyi (2019) The first generation of Chinese art song : Dis ... of Doctor of Musical Arts. Lowa. [in English]. 